\title{
A Critical Assessment of Select Editorial Opinions in The Yoruba News
}

\author{
Taiwo Olunlade \\ Department of African Languages, Literatures and Communication Arts \\ Lagos State University, Nigeria \\ taiwo.olunlade@lasu.edu.ng \\ satodun@gmail.com
}

\begin{abstract}
The emergence of new technologies could not have come at a more auspicious moment, for we learn early everything we know about the world around us through one form of the media or another. Before the advent of this impressive array of media technology, information dissemination was limited to the newspaper, radio, or television. Newspapers, in particular, were in vantage position at molding public opinion and creating mass sensibilities on almost every imaginable issue. This was also the case with The Yoruba News, printed and published by D. A. Obasa in Ibadan, especially through its editorial opinions for over two decades from 1924-1945. This essay is an attempt to revisit selected editions of the newspaper for critical re-assessment of the editorial opinions as regards topical issues of that period
\end{abstract}

\section{Introduction}

The emergence of the printed word on the African continent is inextricably tied to the coming of the colonialists. Printing and publishing in Nigeria could be said to be almost two centuries old because the first printing press was established in the country in 1846. The first printing press, which was installed by the Presbyterian Mission in Calabar, was solely to print religious materials for the use of the church and her converts. The Reverend Henry Townsend later set up a printing press and printing school in Abeokuta some eight years later, and in 1859 founded İwé Íroyin, a bi-weekly Yoruba language newspaper. In 1860, İwé İroyin became a bilingual publication with the inclusion of an English language supplement. As remarked by Kalejaiye, Atofojọmọ, \& Odunlami (2006), this was "by no means a mean achievement 
even by today's standard because there is hardly any bilingual newspaper on the newsstand today" (14). Akalugo (2001) maintained that "the newspaper ended suddenly in October 1867 as a result of a popular uprising which led to the expulsion of Europeans from Abeokuta and the destruction of the printing press" (7).

Quite a number of publications were published from late in the nineteenth century and early twentieth century. These titles included daily, bi-weekly and monthly newspapers. As Ogunsina (2002) noted, with the exception of the provincial weekly newspapers, most of these publications were produced in Lagos. Some of these newspapers were published in indigenous languages. This, according to him, created an upsurge of interest in Yoruba language and literature, which subsequently found expression in Yoruba language journalism. This gave rise to a number of newspapers in the Yoruba language. One of these was The Yoruba News, which is the subject of this study.

The Yorubá News had a number of Yoruba newspapers as its precursors. Its notable precursors were Iwe Irohin Eko which was established in 1888 by Andrew M. Thomas; Iwe Eko in 1891 by Rev. J. Vernal; Nigbati Owo Ba Dile by CMS in 1910; Eko Akete by Adeoye Deniga in 1922; and Eleti Ofe by E.A. Akintan in 1923. It was in 1924 that Obasa joined the train of newspaper proprietors he established a bilingual newspaper named The Yoruba News which was based in Ibadan. The choice of Ibadan for The Yoruba News by Obasa was of immense benefit. As noted by Akínyẹmí (2017),

Obasa's choice of Ibadan as the location of his printing press was strategic none of the other printing press companies already in existence in Nigeria had an office in Ibadan. They were all based in Lagos and Abeokuta. So, with the opening of Ilare Printing Press in Ibadan, Ọbasá was able to draw patronage from Ibadan and other cities (1).

The Yoruba News, published by Obasa, was a provincial newspaper based in Ibadan. As corroborated by Akangbe (2018), the coverage of The Yorubá News was commendable because its news stories were not limited to its Ibadan localé, it appreciably published local, protectorate, national, and international news. These were the hallmarks of every edition of the newspaper right from its inception. In the same vein, its circulation strength went beyond Ibadan, which was its base and, its patronage also had a fairly national spread.

The role of newspapers, irrespective of where it is based, and what language its medium of communication is, either English or indigenous language, has been well established by various scholars and researchers. Newspapers are potent instrument of political development, social awareness, and economic growth. The Yoruba News is no exception. Its editorial opinions especially contributed significantly to the evolution and development of print journalism 
in Nigeria. This shall be seen as we make a critical assessment of the opinions of the newspaper's editors in this study.

\section{Research Methodology}

Having gathered a sizeable number of editions of The Yoruba News from 1924-1945, a random selection of five (5) editorial opinions on such diverse but topical issues as politics, religion, and social issues were isolated as data for this research. An eclectic mix of approaches, strategies, and theories was adopted to enable a critical evaluation of the selected editorials as effective journalistic templates. This methodology enabled the use of linguistic theories, stylistics approaches, and strategies of close reading to provide commentaries which are objective and scientific, based on concrete quantifiable data and applied in a systematic way. At the same time, a "close-reading" of the editorials allowed an impressionistic, intuitive, and randomized but not superficial assessment which emphasizes the connection between the journalistic language of the editorials and the everyday language of the newspaper reader. This has enabled the editorial opinions to be assessed critically in terms of its impact on the readers of the newspaper and by extension and implication, the society.

\section{Analysis and Discussion}

An editorial is an article in a newspaper or magazine that expresses the opinion of its editor or publisher. Editorials are carefully written to persuade the readers. Its goal is to spur the readers to some specific action with a view to getting them to agree with the writer. Indirectly, editorials have a way of influencing readers to support or denounce a cause. Not all editorials take sides on an issue but all have one or more of the following purposes to accomplish: inform, promote, praise, denounce, or entertain. Newspapers often publish editorial pieces that are in line with their editorial slants. Occasionally, dissenting opinions are given opportunity to promote a balanced discussion. Basically, editorials present a thesis, build on an argument that persuade readers or influence readers to think and see things the way the newspaper does.

\section{Exhibit 1:}

The Yoruba News of Tuesday September 13, 1938 falls under the social category as it tackles an educational issue. It was titled "The W.A.S.U. and African Education." W.A.S.U. is the acronym for the West African Students Union, and the thrust of the message in the editorial was the educational empowerment of the African students. The editorial stems from the presentation given by Dr. Hastings R. Banda on the August 6, 1938. In his talk, Dr. Banda discussed opportunities and facilities available to African students in the United 
States of America should they aspire to further their education in that country. He strongly urged the concerned students to strive to be the best not only for their own sake but for the sake of the African race. He also specifically advocated for American education and culture for African students.

A close reading of the text reveals that The Yoruba News is favorably disposed to Banda's message in its editorial opinion. It gave a robust bio-data of the speaker's educational attainment as his credentials, which provided him the authority to make such advocacy. The editorial remarked that: Dr. Banda "was educated in America, where through the wonderful stuff of which he was possessed, he obtained his degree of Bachelor of Philosophy (Ph.B.) from the University of Chicago; and that of Doctor of Medicine (M.D.) from McHarry Medical College." These qualification, as advocated in the editorial, gave the speaker the authority to advise his audience to go for the numerous scholarships which were more easily obtained by African students than the Afro-Americans, provided the former possessed the required "stuff". The editorial, basically educational in thrust, was however, a veiled commentary on the social, educational, political, and economic conditions of Africa and peoples at the time.

\section{Exhibit 2:}

The editorial pages of The Yoruba News August 5 - 12, 1930 appeared on pages 5 and 6 of the bilingual newspaper. They were informed commentaries on three separate topical issues. "Where Are We" is a philosophical position on the socio-psychological of the "Been-to" syndrome among the educated elite of that time. "Been-to" was a snide reference to those Africans, who had had the opportunity to travel to England, the United States of America, or any other part of Europe for educational pursuit who then returned to Africa and started to behave arrogantly by deriding other Africans who were yet to (and may never, for various reasons) visit the white man's land. The editorial notes that: "In trying to be like the white man the would-be European cannot be ignorant of how far short of his ideal he stands." It added that: "He lives a purely artificial life showing a stiff front over an unsound interior, and he so far forgets himself sometimes that he mates with the wrong half: a European woman. How incongruous?"

A close reading and analysis of this editorial reveals a philosophical exploration of the mentality of the average "Been-to" and employs quotations and rhetorical questioning to attempt a tug or poke at the conscience of those being addressed: "A coloured man on his return after a stay in England or other parts of Europe is neither FISH nor FLESH" the newspaper editorial 
quotes "a well-known personage." It also gives a religious bent to the affair with the quote that:

Trying to be gods, the Angels fell,

Trying to be Angels, man fell.

It was the considered opinion of this editorial that whatever success a man may acquire, be it in form of financial, material, certificate, possession, etc. is a gift of God, and should be utilized for the benefit of others, otherwise it becomes worthless.

This editorial provides concrete data to support existing notions in the society of that time. A stylistic analysis is, however, not only about interpretation. For instance, when it is engaged in straight textual interpretation as done in this essay, it often tries to back the impressionistic hunches of common readers with hard linguistic data. For example, the editorial suggests that: "many of our people manage to go to Europe for profession..." Stylistics may suggest new interpretations of words or even entire literary works based on new or changing linguistic evidence; hence the word profession connotes a semantic change and implies that Africans go to Europe to acquire professional skills and education generally to better their lots.

\section{Exhibit 3:}

The editorial of The Yoruba News of Tuesday, February 25, 1933 was bilingual. There was the commentary in English on "The passing of King George V". It chronicled "with deepest regret" the home call of His Late Majesty, King George V, on the $21^{\text {st }}$ of January 1933 and noted that: "The death of his late Majesty has remove (sic) a great king who in his life time was regarded as a real father of his people and a great power for good not only in Europe but all over the world." The encomiums showered on the deceased monarch was effusive. King George V, according to this editorial write-up, was "the greatest monarch in Europe and throughout the whole world, over whose empire the sun never sets. The late king was to European and the world's politics what the 'governor' is to a locomotive engine, and no Ruler is ever satisfied until he shall have seen His Late Majesty, King George V, or his principal Ministers of state as to the right steps to take in the management of their countries."

Linguists argue that a literary effect is created simultaneously in terms of both form and content. In the exhibit above, the words chosen manifest not only the political subjugation of Africa by the British imperialism but also a mental subservience by the black man to the British and European dictatorship. Lexical items and expressions such as "loyal subject of the British 
Empire", "abiding loyalty", and "the greatest monarch" suggest an inferiority complex and colonial mentality on the part of the writer of this editorial. This, of course, does not portray a full picture of that era, as there were also those who were radical thinkers, firmly opposed to the British cultural and political imperialism of the time. The impression given by the choice of words used, the grammatical structure and overall imagery paints nothing but a picture of subservience and undiscriminating loyalty to the British crown.

\section{Exhibit 4:}

The Yoruba News editorial of Tuesday April 30, 1940 was written in Yoruba language. Being a bilingual (Yoruba/English) publication officially, this is not strange. This commentary was entitled "Irohin Ogun Lati Ilu Oyinbo" (War news from the White man's country). This exhibit is numbered chronologically as the editorial writer marshalled his/her argument to its logical conclusion. The editorial is a commentary on a war between Finland and Russia. Finland was about to be overrun by the Russian forces so she appealed to the League of Nations for intervention. Britain and France promised to assist the Finns but Norway and Sweden refused to allow the British and French forces access to their territories through which they must march to get to Finland. This refusal was because Norway and Sweden both feared upsetting Germany which was an ally of Russia. Eventually, Denmark and other European countries were dragged into the war with all of Europe turning into one big battlefield.

The editorial above is written in highly charged political language and may seem daunting to analyze at first. However, one way to begin is to identify some linguistic features utilized in the text. For instance, the editorial is crafted mainly in reported speech and there is a large number of passive verbs to indicate a certain degree of evasiveness. Obviously, it is more a summary of a report than an informed commentary of the situation being reported.

In journalism, the write-up would not count as an editorial opinion but rather an adaptation of a news report. However, Yoruba readers of the editorial, would argue that the very title already indicates that it is a report of a war going on in Europe: "İroyin Ogun Láti Illú Oyìnbo". A direct translation would be read: Report of war from the Whiteman's land. Further, it is a continuation of a previous report as captured in the opening lines: $E$ o ránt' ${ }^{\prime} e^{\prime}$ nígbà tí a te íroyin ogun tí a tẹ kẹ́hìn, a sọ nígbà náà pe..." (You will recall that when we published the previous report of the war we said then that....). Of course, the tools of translation, transliteration, and comparative analysis would come in handy here to capture or reveal the essence of the contents of the editorial being examined here. 


\section{Exhibit 5:}

The editorial opinion of The Yoruba News of October 28, 1924 focused on "The Right Thing" which in the newspaper's view was to invest in the future through the establishment and funding of more educational institutions in West Africa generally and Nigeria in particular. Though a basically education-oriented commentary, it was also rather philosophical noting that: "the power of discernment through which every human being is able to appreciate whatever is good, right and fitting in nature is bestowed by the bountiful creator upon every individual." Another philosophical insight in the editorial states that, "many people who know and speak what is true and right generally shrink back with fear when it comes to the point of acting - especially so when their personal interests are involved."

The thrust of the message, however, is fundamentally education and its development in colonial Nigeria. It called for the establishment of more schools through self-sacrifice and perseverance on the part of both the individual and society. He cited the example of Samuel Ajayi Crowther and the "present" staff of the famous Achimota College, Gold Coast (now Ghana). One of the staff of Achimota was reportedly offered directorship elsewhere, while another was enticed with an annual salary of 2,000 pounds by public high schools in Australia but they declined and chose to come back to West Africa and joined the staff of the celebrated institution. "This is the best way of doing the right thing for the good of the country and is worthy of emulation", the editorial concluded.

The data presented above may be analyzed and interpreted at different levels and in various ways depending on whether one chooses to do a stylistic analysis, linguistic analysis, or otherwise. What is important in the end is a credible data analysis that gives as objective an interpretation as is possible within the given circumstances. The reason for this position is that having used an eclectic model all through, there is no way subjectivity of perceptions will not color interpretations. From linguistic perspective, there is always a gap between the linguistic features identified in the text and the interpretation.

In terms of grammatical structure, some of the sentences are quaint but their semantic implications are clear enough. There are some lexical oddities too. However, this may be typographic error because since then, language usage and meaning of that time, whether English or Yoruba, have undergone some transformations. 


\section{Findings}

This study, which attempted a critical assessment of selected editorial opinions from the defunct Yorübá/English bilingual newspaper The Yorübá News has the following findings:

i. $\quad$ The editorial writings of The Yoruba News covered a broad spectrum of topical issues in Nigeria and West African colonial societies in particular and colonial African societies in general as recorded in the editorials concerning education in the Gold Coast, Nyasaland, and the United Kingdom and United States of America as well as comments on non-Nigerian notable figures such as Dr. Aggrey of the Gold Coast and Dr. Hastings Banda of Southern Africa.

ii. The editorials were relatively short and tended to be more of summaries of addresses given at meetings. For instance, the first editorial discussed in this essay titled: "The W.A.S.U. and African Education" was a mere recap of Dr. Hastings R. Banda's presentation at a meeting of West African Students Union on August 6, 1938.

iii. Some of the editorial were more of straightforward news reporting. For example, the fourth editorial which was written in Yoruba and titled "Irohin Ogun lati Ilu Oyinbo" was just a report of the on-going war activities.

iv. Some editorials treated more than one topical issue as seen in the second editorial discussed in this essay. In such instances, the editorials took the form of short commentaries on the multiple subjects that were treated.

\section{Conclusion}

In conclusion, a re-assessment of the editorial opinions of The Yoruba News which was our focus in this essay reveals that editorial positions of the newspapers of the time contributed significantly to the political and socio-cultural sophistication of the indigenous population and motivated the evolution and development of print journalism in Yorubaland in particular and Nigeria in general.

\section{Bibliography}

Akalugo, B.N. History of Nigerian Mass Media. Ado-Ekiti: C. Ahabomaka Publishing, 2001.

Akangbe C.A. "History, Production and Content of Atọ́ka Photoplay Magazine.” An UnpublishedPh.D. Thesis, University of Ibadan, 2014. 
Akangbe, C. A. “The Content and Form of Ọbasás Weekly Newspaper: Yoru bá News." A paperpresented at The Toyin Falola @65 International Conference on African Knowledges and Alternative Futures held at University of Ibadan, January $29-31,2018$.

Akinyemi, Akintunde. "D.A. Obasa (1879 - 1945): a Yoruba Poet, Culture Activist and LocalIntellectual in Colonial Nigeria." Africa. 87.1, (2017): 1 - 15.

Barry, P. An Introduction to Literary and Cultural Theory. Manchester: Manchester UniversityPress, Manchester, 2002.

Corder, S. Pit. Introducing Applied Linguistics. New York: Penguin Books, 1982.

Kalejaiye, O.J., O. A. Atofojomo, \& A.T. Odunlami. History of Nigerian Mass Media. Lagos:Department of Journalism, Adebola Adegunwa School of Communication, Lagos State University and Centre for Strategic Communication \& Development, Lagos, 2006.

Lyons, J. Language and Linguistics: An Introduction. Cambridge: Cambridge University Press,2009.

Ogunsina, Bisi. Șáá jú Fágúnwà: Àgbéyẹwo Àwọn İtàn Àròsọ Yorủbá Láti İ bẹrẹ Pẹpẹ. Ilọrin: Gbenle Press, 2002.

Olúnládé, T.A. "Yorubá Newspapers' Mottos: A literary Analysis" In Indigenous Language Mediain Africa, Abiodun Salawu (ed.). Lagos: Centre for Black and African Arts and Civilization(CBAAC), 2006, pp.71-85.

Olúnládé, T.A. "Notes on Yoruba Newspapers 1859-2002" In The Yorübá in Transition, History,Values and Modernity. Toyin Falola Ann Genova (eds.), Durham: Carolina AcademicPress, 2006, pp.1-11. 